\title{
Evaluating Occupational Risk Factors among Golzar rug weavers, Kerman, Iran
}

\author{
Zahmatkesh R, MD ${ }^{1}$, Khanjani N, $\mathrm{PhD}^{2 *}$, Ghotbi Ravandi M R, $\mathrm{PhD}^{3}$ \\ 1- Head of Disease Unit, Kerman Province Health Authority, Kerman, Iran. 2- Assistant Prof. Dept. Epidemiology and \\ Statistics, Kerman University of Medical Sciences, Kerman, Iran. 3. Assistant Prof., Dept. of Occupational Health, Kerman \\ University of Medical Sciences, Kerman, Iran
}

\begin{abstract}
Received: October 2011, Accepted: November 2011

Background: Rug weaving is an important source of income in rural areas of Kerman and hand woven rugs are considered as the most important non-petroleum export of Iran. In this study, we describe the working environment as well as the occupational risk factors of these rug weavers.

Materials and Methods: This study was performed in the Golzar region including Shirinak, Chartagh and Babe Shamil villages. The workplaces were identified and the hazards of each workshop were determined using the study checklist. The workers were also screened for medical conditions.

Results: The average age of the workers was 29 years. The work place evaluation showed that the floor, wall, ceiling, light, temperature and general condition of most of the workplaces was inappropriate and non-standard, and needed major changes. The average working hours were 9.1 hours a day. Medical problems such as visual disturbances, musculoskeletal problems, psychological disorders, gynecological disorders, goiter and tightness of breath were discovered in the workers.

Conclusion: Many rug weavers still work in improper conditions, and need occupational health knowledge and financial support to improve the physical characteristics of their workplaces and prevent debilitating disorders.
\end{abstract}

Key Words: Rug weavers, Kerman, Occupational risk assessment

\section{Introduction}

Handmade rug industry is one of the most important traditional handicrafts in Iran. Considering its long history in Iran and the employment of many people in this field, the carpet industry can be regarded a complementary income for rural families [1]. Kerman province with a population of $2,652,413$ people and 183,193 square kilometers surface is located in the South East of Iran [2]. It is among the dry regions of Iran with low rainfall and a desert climate. Small industries such as rug weaving have been popular in this area all throughout its history. The town of Bardsir with a population of 89,265 people is located 60 kilometers south west of Kerman [2]. Golzar is one of the rural areas of Bardsir and is located 65 kilometers South East of Bardsir. The main income of people in this area is rug weaving and farming.

\footnotetext{
* Corresponding Author: Narges Khanjani, Dept. of Epidemiology and Statistics, Kerman University of Medical Sciences, Kerman, Iran.

Email: n_khanjani@kmu.ac.ir
} 
The decrease in rainfall in the recent years and continuous droughts have led to increased emigration from this area, but the people who have not been able to emigrate have chosen rug weaving as the main source of income for themselves. These people have prepared a small workplace in their houses with little infrastructure and in a completely unhealthy and improper environment. Most of the people in the family including women, young girls and even children work as rug weavers.

According to previous studies, poor working conditions and awkward positions during rug weaving can lead to musculoskeletal disorders [3-6], bone deformities such as pelvic deformities and kyphosis [7]. Studies have reported up to $98 \%$ awkward postures and wrong workstation positions among these people. [3]. In the past, pelvic deformities in young women have led to failure in normal vaginal delivery and maternal mortality. Carpal Tunnel Syndrome [8, 9] byssinosis [10] astigmatism and myopia $[1,11,12]$, psychological disorders and endocrine disorders [1] are among the other disorders reported in this job group. Also, a study from India has reported that respiratory symptoms, backache and joint pains occurred more often in the carpet weaver population [13].

The working hours in this industry is usually variable, but, mainly in order to send the rug to the market sooner, the rug weaver may spend long hours in their workplace [3]. In one study $11.3 \%$ of the population worked more than 11 hours a day [3].

There are few studies about the occupational hazards in rug weavers' working environment. In this study, we evaluated and documented the occupational risk factors of rug weavers in the Golzar region of Iran, in order to provide assistance to the rug weavers in promoting their workshops, to screen and refer troubled workers to physicians, and also to provide proper information about the risk factors and disorder prevention to the villagers. This project was part of a national project financially supported by the Iranian Ministry of Health and Medical Education for promoting the working conditions of rural rug weavers.

\section{Materials and Methods}

This study was an observational qualitative, descriptive study. The study was approved by the Ministry of Health and Medical Educations Ethics Committee before commencement. The study was performed in the Golzar region and the Shirinak, Chartagh and Babe Shamil villages. Although in this study 630 rug weaving workshops were identified, a number of 56 workplaces were chosen for intervention and promotion based on these priorities: families who do rug-weaving all throughout the year and carpet weaving is the main source of their income; workplaces in which a higher number of people were working at and therefore would benefit more from the interventions; families who were more cooperative and interested in promoting their workplaces; families who were financially more distressed.

The workplaces were identified and registered by the local health staff, written consent forms were signed by all the participants. Data were collected by trained local healthcare workers using an extensive check list and 7 forms in which the hazards of each of the workshops were determined. Form 1 was a checklist determining the hazards of the workplace, in form 2 the budget for the workplace was estimated, form 3 and 4 included the necessary equipment suggestions for reconstruction and permission for inquiring the material. In form 5 and 6 the local health care workers 
documented the reconstruction progress and its details, and finally form 7 was completed when the job was finished and included a summary of the work done and its final report. The rug weavers were screened for medical problems by trained general practitioners and a checklist including different medical complications was completed. Those with medical problems were registered and referred to medical centers.
After the risk factors of each workshop were determined, proper interventions were done. Data were collected by the checklist and forms were analyzed using SPSS. Simple statistics and qualitative descriptions were used to describe the occupational risk factors of these workers. Also, statistical tests were used to compare some factors in different grounds.

Table 1: Characteristics of rug weaving workshops in the Golzar region.

\begin{tabular}{|c|c|c|c|c|c|c|c|c|c|}
\hline \multirow[b]{3}{*}{ Characteristics } & \multicolumn{8}{|c|}{ Regions } & \multirow{3}{*}{ Total } \\
\hline & \multicolumn{2}{|c|}{ Golzar } & \multicolumn{2}{|c|}{ Chartagh } & \multicolumn{2}{|c|}{ Shirinak } & \multicolumn{2}{|c|}{ Sahebabad } & \\
\hline & $\mathrm{N}$ & $\%$ & $\mathrm{~N}$ & $\%$ & $\mathrm{~N}$ & $\%$ & $\mathrm{~N}$ & $\%$ & \\
\hline $\begin{array}{l}\text { - Available } \\
\text { workshops }\end{array}$ & 376 & 60 & 148 & 23 & 68 & 11 & 38 & 6 & 630 \\
\hline $\begin{array}{l}\text { - Registered } \\
\text { workshops }\end{array}$ & 325 & 64 & 107 & 21 & 59 & 12 & 15 & 3 & 506 \\
\hline $\begin{array}{l}\text { - Number of } \\
\text { workers }\end{array}$ & 568 & 58 & 243 & 25 & 91 & 9 & 75 & 8 & 977 \\
\hline $\begin{array}{l}\text { - Registered } \\
\text { workers }\end{array}$ & 445 & 66 & 125 & 18 & 78 & 12 & 30 & 4 & 678 \\
\hline - Workers under & & & & & & & & & \\
\hline $\begin{array}{l}15 \text { yrs } \\
\text { - Workers } 15 \text { to }\end{array}$ & 1 & 4 & 20 & 71 & 3 & 11 & 4 & 14 & 28 \\
\hline $64 \mathrm{yrs}$ & 567 & 60 & 223 & 23 & 88 & 9 & 71 & 7 & 949 \\
\hline
\end{tabular}

\section{Results}

In this area, there were a total of 630 rug weaving workshops in which 977 people worked. The characteristics of the workplaces are shown in table 1 . The rug weaving workplace in this area was a $3 \times 4$ meter room or smaller in which a rug weaving frame was set up in the distance of about 50 to 70 centimeters from one of the walls and the rug weavers (alone or accompanied by others) would sit on a thin and non-standard strip of wood besides the frame.
All of the rug weaving rooms had a two flap door which could not be opened easily. In some places $(30 \%, \mathrm{n}=188)$, above the door, pieces of glass had been placed as a window in which natural light could pass through, although in many workplaces (about 33\%, $\mathrm{n}=207$ ) there was no proper window. About $60 \%(n=375)$ of the workplaces had insufficient natural light and did not have enough artificial light either. In all the work rooms a lamp was hung from the middle of the ceiling and its location was in front of the rug weaver and behind the frame. 
In about $72 \%(\mathrm{n}=453)$ of the workplaces after the workers experienced dull sight, a small hole of no more than $30 \times 40$ centimeters was made on one of the walls, however in winter, this hole was covered with a piece of tough fabric or plastic to prevent the cold coming in. The floor surface in about $81 \%(n=510)$ of the workplaces was covered by cement, but was uneven. The surface of the rest of the workplaces was dirt and had no cover. About $24 \%(n=151)$ of the workshop floors were defective and needed reconstruction. The walls of about $60 \%(n=375)$ of the workplaces were covered with mud and straw or stones, and were dark and smoky which increased the darkness of the room. One of the most important problems of rug weaving workplaces was the fact that this space was also used as the living room, kitchen, storage and even for animal accommodation. Some people even used oil burning lamps and picnic stoves besides the rug frame. The weaving tools were set on the frame in a way that the probability of falling was very high. The frame joints were loose, without proper firmness and the probability of an accident happening was very high. In the rug weaving process a wide array of people, from 5 year old girls to women and old men participated. Their mean age was 29.7 \pm 9.1 (Min=5, Max=70). All of them sat on the same thin and equal heighted wood strip, for example an adult with $170 \mathrm{~cm}$ height and a child with $100 \mathrm{~cm}$ height would sit on the same heighted bench.

Table 2: The number and proportion of workplaces with problems (risk factors) in different regions of the study.

\begin{tabular}{|c|c|c|c|c|c|c|c|c|}
\hline \multirow[b]{3}{*}{ Workplace hazards } & \multicolumn{6}{|c|}{ Regions } & \multirow{2}{*}{\multicolumn{2}{|c|}{ Total }} \\
\hline & \multicolumn{2}{|c|}{ Golzar } & \multicolumn{2}{|c|}{ Chartagh } & \multicolumn{2}{|c|}{ Shirinak } & & \\
\hline & $\mathrm{N}$ & $\%$ & $\mathrm{~N}$ & $\%$ & $\mathrm{~N}$ & $\%$ & $\mathrm{~N}$ & $\%$ \\
\hline - Improper sitting place * & 325 & 86.4 & 107 & 72.3 & 59 & 86.8 & .91 & 77.9 \\
\hline - Without first aid kit * & 325 & 86.4 & 107 & 72.3 & 59 & 86.8 & 91 & 77.9 \\
\hline - Insufficient light & 240 & 63.8 & 94 & 63.5 & 44 & 64.7 & 78 & 60.0 \\
\hline - Dark or damaged walls * & 223 & 59.3 & 107 & 72.3 & 46 & 67.6 & 76 & 59.7 \\
\hline - Dark or damaged ceiling * & 224 & 59.6 & 106 & 71.6 & 45 & 66.2 & 75 & 59.5 \\
\hline - Dusty working environment * & 229 & 60.9 & 105 & 70.9 & 38 & 55.9 & 72 & 59.0 \\
\hline $\begin{array}{l}\text { - Small, insufficient windows or no } \\
\text { window * }\end{array}$ & 113 & 30.0 & 64 & 43.2 & 30 & 44.1 & 07 & 32.8 \\
\hline - Improper workshop floor * & 24 & 6.4 & 86 & 58.1 & 43 & 63.2 & 53 & 24.2 \\
\hline - Improper cold/heat * & 55 & 14.6 & 36 & 24.3 & 32 & 47.0 & 23 & 19.5 \\
\hline $\begin{array}{l}\text { - Defective working tools or } \\
\text { improper placement of tools* }\end{array}$ & 14 & 3.7 & 94 & 63.5 & 15 & 22.0 & 23 & 19.5 \\
\hline $\begin{array}{l}\text { - Number of workers visited by a } \\
\text { doctor before * }\end{array}$ & 44 & 11.7 & 11 & 7.4 & 47 & 69.1 & 02 & 16.2 \\
\hline
\end{tabular}

* Difference in regions statistically significant at the 0.05 level

The rug weaver would sit alone or with others on a wooden strip without a cushion or any soft cover. In about $60 \%$ of the cases $(n=377)$ it was covered by a piece of fabric, but it was still too firm and inappropriate. The sitting position in most cases (about $78 \%, \mathrm{n}=762$ ) was incorrect, and included sitting with folded knees, squatting, bending the knees and sitting between legs or sitting under the frame. The risk factors of these work places and their frequency are listed in table 2. In all items listed, the Golzar region had a better situation 
in comparison to Chartagh and Shirinak. However in Shirinak the number of workers $(69.1 \%, n=47)$ visited by a doctor was higher. The average working hours of the rug weavers was $9.1 \pm 1.3$ hours, the working hours varied for different people. For example women worked between or after doing their other domestic tasks such as cooking, taking care of children, washing, cleaning and animal husbandry and barely worked more than 4 hours a day in rug weaving. However, about $79 \%(\mathrm{n}=771)$ of the cases which included young girls, teenagers and children worked continuously and between 8 to 12 hours a day.
Most of the rug weavers were women, unmarried girls, and children or teenagers who had started working since a young age. The health of the workers was a matter of concern, as many had already gained disorders such as visual disturbances, musculoskeletal disorders, gynecological disorders, tightness of breath and psychological disorders. The disorders discovered and their frequencies have been mentioned in table 3. The Shirinak region had the highest number of workers with medical problems, except goiter. Goiter was found more in the Golzar region.

Table 3: The number and proportion of rug weavers with medical problems in different regions of study

\begin{tabular}{|c|c|c|c|c|c|c|c|c|}
\hline \multirow{3}{*}{ Medical problem } & \multicolumn{6}{|c|}{ Regions } & \multirow{2}{*}{\multicolumn{2}{|c|}{ Total }} \\
\hline & \multicolumn{2}{|c|}{ Golzar } & \multicolumn{2}{|c|}{ Chartagh } & \multicolumn{2}{|c|}{ Shirinak } & & \\
\hline & $\mathrm{N}$ & $\%$ & $\mathrm{~N}$ & $\%$ & $\mathrm{~N}$ & $\%$ & $\mathrm{~N}$ & $\%$ \\
\hline - Visual disturbance* & 36 & 6.3 & 4 & 1.6 & 17 & 18.7 & 57 & 5.8 \\
\hline $\begin{array}{l}\text { - Musculoskeletal } \\
\text { disorders * }\end{array}$ & 16 & 2.8 & 2 & 0.8 & 12 & 13.2 & 30 & 3.1 \\
\hline $\begin{array}{l}\text { - Psychological } \\
\text { disorders * }\end{array}$ & 12 & 2.1 & 2 & 0.8 & 5 & 5.5 & 19 & 1.9 \\
\hline $\begin{array}{l}\text { - Gynecological } \\
\text { disorders }\end{array}$ & 5 & 0.8 & 8 & 0.8 & 3 & 3.3 & 10 & 1.0 \\
\hline - Goiter & 7 & 1.2 & 0 & 0 & 1 & 1.1 & 8 & 0.8 \\
\hline - Tightness of breath & 5 & 0.8 & 0 & 0 & 1 & 1.1 & 6 & 0.6 \\
\hline
\end{tabular}

* Difference in regions statistically significant at the 0.05 level

\section{Discussion}

Rug weaving is considered as an important national handcraft. It is a traditional art and one of the most important small industries in Iran. Hand woven rugs are also the most important non-petroleum export product. Therefore, the occupational hygiene and improvement of the working conditions of this specific group is important and has a considerable effect on the nation's economical improvement [3]. Educational programs for the rug weavers conducted by the "Jahad Sazandegi" has started since 1991 [14]. However, still this hard working population need more attention.

In Iran small industries such as rug weaving make $96 \%$ of the total active industries in the country and close to $85 \%$ of the active work force operate in them [3]. Our study and some other studies [15] have shown that rug weavers in parts of Iran are still working in improper conditions that need improvement. However, only a few studies about the health of rug weavers and their occupational risk factors 
have been done. Similar to our study, another study has reported the lack of proper seat, leg clearance, adjustment mechanisms, together with incorrect weaving heights, which have forced the weavers to work in constrain and harmful postures [3] and have shown that most rug weavers sat on a wood strip or the ground during working. In about half of the workers there was not enough space for their legs and in most cases the leg position was incorrect and almost all workers were working in awkward body positions [3]. Studies have shown that musculoskeletal disorders in the rug weavers were significantly higher than the normal population [3, 5] and sitting on hard surfaces such as the situation of rug weavers causes pressure on inter vertebral discs and muscles, and leads to circulating problems [3].

Most of the workplaces had insufficient natural light, and did not have enough artificial light either. In most workplaces, the lamp that was hung from the middle of the ceiling was behind the frame, which not only wasn't a help to the weaver's sight, but because the light would pass through the rug strings and hit the weaver's eye, it caused eye tiredness and impudence. The oil burning lamps and picnic stoves that some people used beside the rug frame, produced smoke, carbon gases and a strong smell which led to respiratory problems, eye itching, headaches and dizziness in the rug weaver and the other members of the family. Also, the closeness of the cooking and heat appliances to the rug frame, in addition to creating a non hygienic environment, could be prone to cause fire and burning disasters.

Most of the workers in our study and others [3] were females with little access to occupational health services and worked continuously between 8 to 12 hours a day. Other studies have also reported workers working long hours, more than 11 hours a day, and even up to 16 hours daily [3]. All of the rug weavers in our study sat on the same heighted bench, therefore some of them had to bend their back and some others had to raise their hands, which is an ergonomically awkward position.

In our study, cases of psychological and endocrine disorders were also discovered, which has also been reported in one other study [1]. The highest complaint in our study was visual disturbances which has also been mentioned in the other studies [11, 12]. Other studies have reported that rug weaving done by young girls and in abnormal positions for long periods, causes bone deformities which is aggravated by poor hygiene and insufficient diets [7]. Since the overwhelming majority of rug weavers' health problems originate from ergonomic risk factors, improvements in their working postures should be a major priority [16].After the main risk factors in our study population were recognized, educational programs such as lectures and instructional films were organized. In order to improve people's understanding of their workplace risk factors, people were asked to cooperate in promoting their own workplaces. The changes that were implied in the workplaces included covering the ceilings with insulated material to keep the temperature inside in winter and summer, whitening the walls, providing proper natural light by making proper windows, correcting the artificial light and correcting the sitting positions. People with specific disorders were referred to medical centers for receiving further assistance.

\section{Conclusions}

Carpet weaving is considered as an important source of income for the people in rural areas of Kerman, and as it is also a beautiful handicraft and a major non petroleum export of 
IR Iran, job satisfaction of the carpet weavers should be a priority for the governmental and health organizations. Job satisfaction surly will have an effect on the quality of their jobs [17]. Therefore it seems, that with worker education and workplace surveillance by the local health authorities, the health and job satisfaction of these people would improve in the future.

\section{Acknowledgement}

The authors would like to thank the Ministry of Health and Medical Education, Kerman Province Health Authorities and Kerman Medical University for supporting this study. The study proposal was also approved by the Environmental Medicine Research Committee of the Kerman Medical University, School of Public Health.

\section{Conflict of interest: Non declared}

\section{References}

1. Baghianimoghadam $\mathrm{MH}$, Aminipour MR, Ehrampoush MH, Vakili M, Dehghani Tafti MH, Fazelpour S, et al. A survey on the relationship between status of the environmental health and health of the carpet workers in rural of Mehriz Yazd, Iran. Toloo-e-Behdasht 2010; 9(29):86-95. [Persian]

2. Rahbar Dehghani A (2007). The statistical year book of Kerman., $1^{\text {nd }}$ ed. Kerman: Yarmand.

3. Choobineh A, Lahmi M, Hosseini M, Khani Jazani R, Shahnavaz H. Musculoskeletal problems in Iranian hand woven carpet industry in Iran. Journal of School of Public Health and Institute of Public Health Research 2003; 2(3(7)):24-9. [Persian]

4. Choubineh A, Lahmi M, Shahnavaz H, Jazani RK, Hosseini M. Musculoskeletal symptoms as related to ergonomic factors in Iranian handwoven carpet industry and general guidelines for workstation design. Int J Occup Saf Ergon 2004; 10(2):157-68

5. Choobineh A, Hosseini M, Lahmi M, Khani Jazani R, Shahnavaz H. Musculoskeletal problems in Iranian hand-woven carpet industry: guidelines for workstation design. Appl Ergon 2007; 38(5):617-24.

6. Motamedzadeh M, Moghimbeigi A. Musculoskeletal disorders among female carpet weavers in Iran. Ergonomics 2011; 17(Epub ahead of print).

7. Chahidi H. Occupational osteopathy of rug weavers. Apropos of 64 cases. J Chir (Paris) 1975; 109(5-6): 633-8.

8. Senveli ME, Turker A, Arda MN, Altinors MN. Bilateral carpal tunnel syndrome in a young carpet weaver. Clin Neurol Neurosurg 1987; 89(4):281-2.

9. Motalebi M, Fakharian E, Hanani M. Carpet weavers and carpal tunnel syndrome (CTE). Behbood 2007; 11(1(32)):77-85.

10. Ozesmi M, Aslan H, Hillerdal G, Rylander R, Ozesmi C, Baris YI. Byssinosis in carpet weavers exposed to wool contaminated with endotoxin. $\mathrm{Br}$ J Ind Med 1987; 44(7):479-83.

11. Akbarzadeh S, Samavati $M$, Mahjoob $\mathrm{H}$. Comparison of refractive errors in carpet weavers and other blue-collar workers. Hakim 2007; 10(1):26-31.

12. Davari MH, Mirzaei H. A relationship between carpet kneading and myopia. Feyz 2001; 5(19): 19-22.

13. Das PK, Shukla KP, Ory FG. An occupational health programme for adults and children in the carpet weaving industry, Mirzapur, India: a case study in the informal sector. Soc Sci Med 1992; 35(10):1293-302.

14. Zamani G, Talebianpour MJ. Taseere amoozeshhaye fanni-herfei (ghalibafi) bar eghtesade roostaian. Eghtesade keshavarzi va tosee 2001; 9(34):301-26.

15. Hajiani E, Pakseresht S. Niazhaye behdashti ghalibafan va kargah-haye ghalibafi dar iran. Goljam 2007; 8:43-55.

16. Choubineh A, Shahnavaz H, Lahmi M. Major health risk factors in Iranian hand woven carpet industry. Int J Occup Saf Ergon 2004; 10(1):6578.

17. Rezaei M. Carpet weavers' job satisfaction in east Azarbaijan and Isfahan. Goljaam 2006; Summer(3):25-34. 